\title{
EFFECT OF INTRAVENOUS MAGNESIUM SULPHATE ON ATROPINE AND OXIME USAGE IN ACUTE ORGANOPHOSPHATE TOXICITY
}

\author{
Tarek Afify $^{a^{*}}$, MSc; Usama M. El-Barrany ${ }^{b}$, MD; Hisham Elshikhiby ${ }^{c}$, MD; \\ Mohamed Adly ${ }^{b}$, MD; Samah Fathy ${ }^{b}$, MD \\ National Toxicology Center (NECTR) ${ }^{a}$, Department of Forensic Medicine and \\ Clinical Toxicology ${ }^{\mathrm{b}}$, Department of Pharmacology ${ }^{\mathrm{c}}$, Kasr Al Ainy Faculty of \\ Medicine, Cairo University
}

\begin{abstract}
Background: organophosphates are widely used in agriculture as pesticides, in industry as softening agents and additives to lubricants. They are also used as household chemicals, allowing many opportunities for acute poisoning, as well as for occupational use. Besides, organophosphates being nerve agents are used in military setting or in terrorist attacks. Organophosphates self-poisoning is an important clinical problem in rural regions of the developing world, and kills an estimated 200000 people every year. Unintentional poisoning kills far fewer people but is a problem in places where highly toxic organophosphates pesticides are available. Patients and methods: a comparative study in which iv magnesium sulphate was given in a dose of $1 \mathrm{~g} / 6 \mathrm{hrs}$ for $24 \mathrm{hrs}$ to 50 patients acutely intoxicated with organophosphate who are treated with atropine and oximes (group i) and compared to 50 patients who are not given iv magnesium sulphate who are treated with atropine and oximes then atropine use and oxime use in the two groups are compared. Results: comparison between the control and the group which took magnesium sulphate showed a statistical significant difference between the 2 groups in the atropine and the oxime use $(p<0.05)$. Conclusion: magnesium sulphate decreases atropine and oxime use in acute organophosphate toxicity. Such information may in turn guide clinical practice to the use of magnesium sulphate in acute organophosphate toxicity and so more studies should be done to confirm these findings.

Keywords: magnesium sulphate - acute organophosphate toxicity- - atropine use-oxime use

Conflicts of interest: None declared.

*Corresponding author. Department of Forensic Medicine and Clinical Toxicology, Kasr Al Ainy Faculty of Medicine, Cairo University.

E-mail address: afifytarek@gmail.com
\end{abstract}

\section{INTRODUCTION}

Organophosphates are widely used in agriculture as pesticides, in industry as softening agents and additives to lubricants. They are also used as household chemicals, allowing many opportunities for acute poisoning, as well as for occupational use. Besides, organophosphates being nerve agents are used in military setting or in terrorist attacks (Roberts and Aaron, 2007).

Organophosphates self-poisoning is an important clinical problem in rural regions of the developing world, and kills an estimated 200000 people every 
year. Unintentional poisoning kills far fewer people but is a problem in places where highly toxic organophosphates pesticides are available (Eddleston et al., 2004).

A review of poisoning studies in developing countries reveals that pesticide poisonings associated with high mortality rates are usually the result of self-poisoning. A great number of victims were present in rural regions due to the widespread availability of acutely toxic pesticides used in agriculture (Ahmad et al., 2009).

\section{PATIENTS \& METHODS:}

This unicenter, randomized, prospective study was conducted at National Toxicology center (NECTR) Cairo University. The first patient was enrolled on August 2 2013, and the last enrolled on October 10, 2014.

The diagnosis of acute OP poisoning was based upon history of oral ingestion of a known OP, presence of characteristic symptoms and signs of muscarinic and nicotinic involvement, and reduced levels of plasma choline esterase.

Patients were excluded from the study if they had concomitant ingestion of other drugs in a suicidal attempt. Patients were divided into two groups and in a systematic sampling, every second eligible patient was chosen to undergo MgSO 4 treatment.
We studied 100 patients (56 females, 44 male). Group I consists of fifty patients (25 males, 25 females) received magnesium sulphate ivi (1g/6hr for first $24 \mathrm{hrs}$ ) beside the routine treatment comprising of gastric lavage, administration of $1 \mathrm{~g} / \mathrm{kg}$ activated charcoal and serial administration of activated charcoal, bathing with water and soap at least three times a day, appropriate bolus and maintenance doses of atropine (the endpoint of atropinization was drying of secretions, flashing, tachycardia and mydriasis), and appropriate doses of obidoxime. Group II consists of fifty patients (31 females, 19 males) received the routine treatment without magnesium sulphate.

The starting dose of obidoxime was 250-500mg IV Additional doses were given in a bolus of $250-500 \mathrm{mg} \mathrm{I.V}$. over 30-60 min every 6-12 hours according to severity of poisoning. The ideal dose of obidoxime was determined by monitoring the clinical condition of the patient and serial assessment of cholinesterase levels over a period of several days

\section{RESULTS}

Assessment of plasma choline esterase level (BuChE) levels spectrophotometrically in both groups showed no statistically significant difference between group I and group II in plasma choline esterase level on admission ( $p>0.05)$ (Table 1).

Table (1): Comparison between plasma choline esterase (BuChE) level on admission between group I and group II.

\begin{tabular}{|l|l|l|l|}
\hline & $\begin{array}{l}\text { Group II } \\
\left.\mathbf{M g S O}_{\mathbf{4}} \text { given }\right)\end{array}$ & $\begin{array}{l}\text { Group value } \\
\left.\mathbf{M g S O}_{\mathbf{4}} \text { not given }\right)\end{array}$ & P \\
\hline On admission & 1863 & 1473 & 0.168 \\
\hline
\end{tabular}

*BuChE: Butyryl cholinesterase 
Assessment of the use of oximes in the two groups shows that there is significant difference between oxime's usage in those who received $\mathrm{Mg}$ and those who didn't. In group I, the mean oxime usage is $690 \pm 170 \mathrm{mg}$ (mean \pm standard deviation) and mean oxime usage in group 2 is $775 \pm 192.94 \mathrm{mg}$ (mean \pm standard deviation) (Table 2 , Figure 1).

Assessment of the use of atropine in the two groups shows that there is significant difference in atropine usage between Group I and II. The mean atropine usage in patients who received Magnesium Sulphate beside oxime and atropine is $4 \pm 1.01 \mathrm{mg}$ (mean \pm standard deviation) and mean oxime usage in patients who didn't receive Magnesium Sulphate is $5 \pm 1.34 \mathrm{mg}$ (mean \pm standard deviation) (Table 2 , Figure 1).

Table (2): Comparison between oxime usage and atropine usage in group I and group II

\begin{tabular}{|l|l|l|l|l|l|}
\hline & \multicolumn{2}{|l|}{$\begin{array}{l}\text { Group I } \\
\text { Receiving MgSO } \\
(\mathbf{n = 5 0 )}\end{array}$} & \multicolumn{2}{l}{$\begin{array}{l}\text { Group II } \\
\text { Not receiving MgSO } \\
(\mathbf{n = 5 0 )}\end{array}$} & $\begin{array}{l}\text { P } \\
\text { value }\end{array}$ \\
\hline & $\mathbf{N}$ & \% & N & \% & \\
\hline Obidoxime usage (mg) & & & & & \\
\hline 500 & 19 & 38.0 & 13 & 26.0 & $\mathbf{0 . 0 3 8}$ \\
\hline 750 & 24 & 48.0 & 19 & 38.0 & S \\
\hline 1000 & 7 & 14.0 & 18 & 36.0 & \\
\hline Atropine usage (mg) & & & & & \\
\hline 2 & 5 & 10.0 & 0 & 0.0 & $<0.001$ \\
\hline 3 & 10 & 20.0 & 13 & 26.0 & S \\
\hline 4 & 13 & 26.0 & 0 & 0.0 & \\
\hline 5 & 22 & 44.0 & 14 & 28.0 & \\
\hline 6 & 0 & 0.0 & 18 & 36.0 & \\
\hline 7 & 0 & 0.0 & 5 & 10.0 & \\
\hline
\end{tabular}

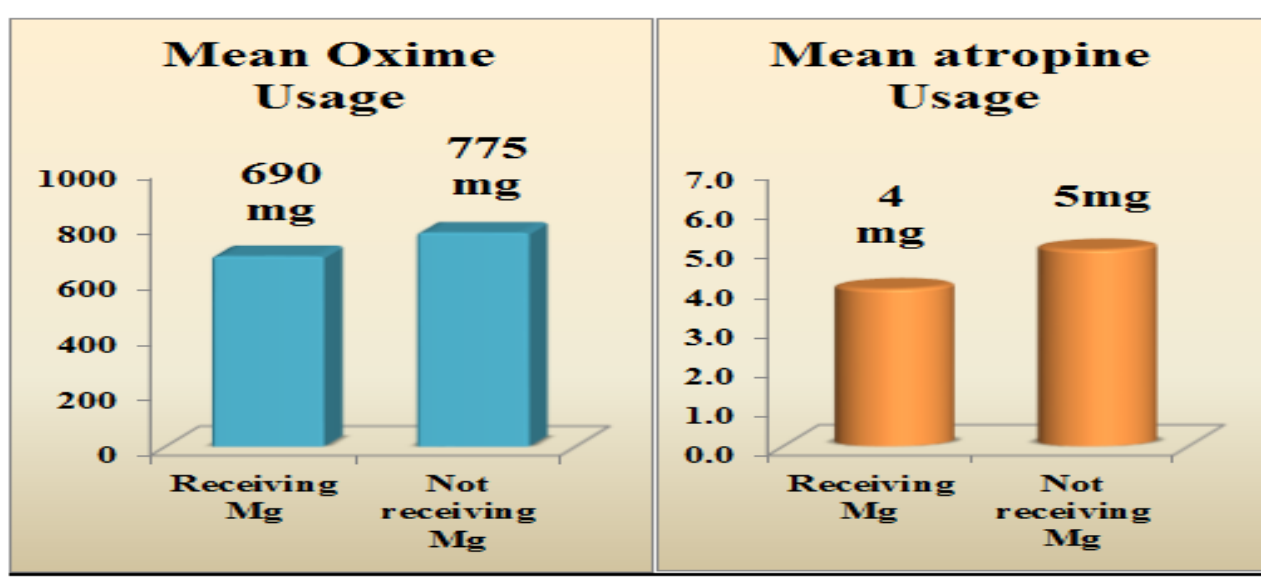

Figure (1): Comparison between mean oxime usage and mean atropine usage in group I and group II.

*Mg: Magnesium Sulphate 


\section{DISCUSSION}

Pesticides result in a huge number of intoxications because of their widespread use and easy accessibility especially in the developing world's agricultural communities and constitute high share of intoxicated patients worldwide, since the only life-saving antidotes for ChE-I pesticide poisoning are oxygen and atropine, the most important issue after resuscitation is to decide the need for atropine. The clinical features of cholinergic poisoning are the trigger for the decision to give atropine (Ballantyne and Marrs, 1992).

Treatment of intoxication with OPs conventionally involves atropine for reduction of muscarinic signs and oximes that increase the rate of hydrolysis of the phosphorylated enzyme acetylcholinesterase (AChE) (Tafuri and Roberts, 1987).

Paudyal, 2008 stated that there is a tendency to give excess atropine, which can be dangerous. So, close observation and dose adjustment was essential to avoid the features of both under- and over-atropinization.

Hypomagnesemia and resistance to atropine have been detected in a group of cattle but this finding has not been repeated in either other animals or humans (Sungur and Guven, 2001).

Our findings show that $\mathrm{MgSO}_{4}$ therapy reduced oxime requirements significantly from $775 \pm 192 \mathrm{mg}$ in control group to $690 \pm 170 \mathrm{mg}$. These results are different from results of Pajoumand et al. (2004), which showed no significant difference.

Our findings show that $\mathrm{MgSO}_{4}$ therapy reduced atropine requirement significantly from $5 \pm 1.34 \mathrm{mg}$ in control group to $4 \pm 1 \mathrm{mg}$. These results are also different from results of
Pajoumand et al. (2004) and Basher et al. (2013), which showed no significant difference.

\section{CONCLUSION}

It is recommended to infuse magnesium sulphate in a dose of $1 \mathrm{~g} / 6$ hrs in acute organophosphate toxicity to reduce the amount of atropine and oximes needed.

Adequate follow up and monitoring of either regimens administered and adequate titration to symptoms may play an important role for clinical improvement of intoxicated patients.

There is other many factors that affect the improvement of the clinical presentations of CHE-I poisoning besides the treatment regimen as type of organophosphate and delay before medical management.

\section{REFERENCES:}

Ahmad M., Rahman F., Ashrafuzzaman M. et al., (2009): Overview of Organophosphorus Compound Poisoning in Bangladesh and Medicolegal Aspects Related to Fatal Cases. JAFMC Bangladesh. Vol 5, No 1.

Ballantyne B. and Marrs T. (1992): Overview of the biological and clinical aspects of organophosphates and carbamates. In Clinical and experimental toxicology of organophosphates and carbamates. Edited by Ballantyne B, Marrs TC. Oxford: Butterworth heinemann; 3-14.

Basher A, Rahman SH, Ghose A. et al. (2013): Phase II study of magnesium sulfate in acute organophosphate pesticide poisoning. Clin Toxicol.; 51(1): 3540. 
Eddleston M., Dawson A., Karalleidde L, et al., (2004): Early management after selfpoisoning with an organophosphorus or carbamate pesticide - a treatment protocol for junior doctors. Critical Care; 8: R391-R397.

Ferrer A (2003): Pesticide poisoning. Ansist Sanit Navar; 26(1): 155171.

Pajoumand A, Shadnia S, Rezaie A, et al. (2004): Benefits of magnesium sulfate in the management of acute human poisoning by organophosphorus insecticides. Hum Exp Toxicol.; 23: 565-569.

Sungur M, and Guven M. (2001): Intensive care management of organophosphate insecticide poisoning. Crit Care J.; 5: 211-215.

Tafuri J, Roberts J. (1987): Organophosphate poisoning. Ann Emerg Med.; 16: 193 -202. 


\section{الملخص العربي}

\section{تأثير كبريتات المغتيسيوم عن طريث الوريد على استخدام الأتروبين وأكسيم في تسمم}

\section{عضوي الفوسفات حاد الفئر}

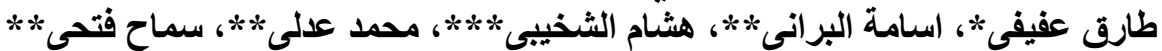

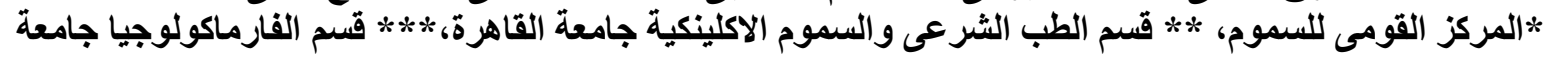
(القاهرة

تستخدم الفوسفات العضوي على نطاق و اسع في الزر اعة كمبيدات للآفات ، وفي الصنات الصناعة كعو امل تلليين

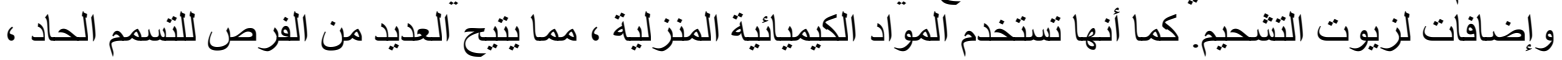

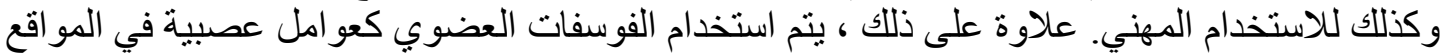

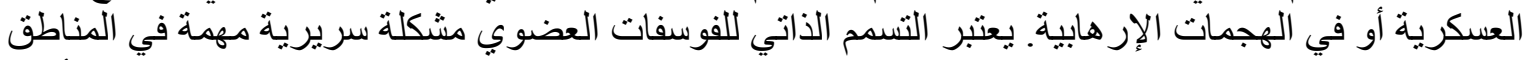
الريفية في العالم النامي ، ويقتل ما يقدر بنحو

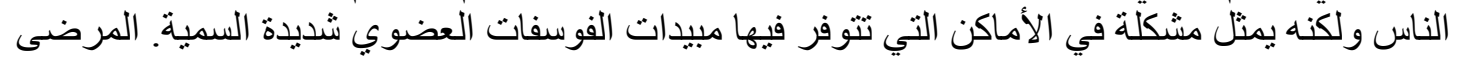

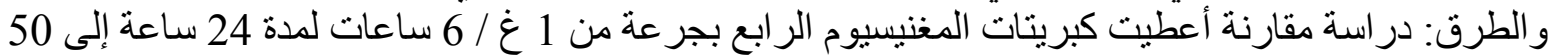

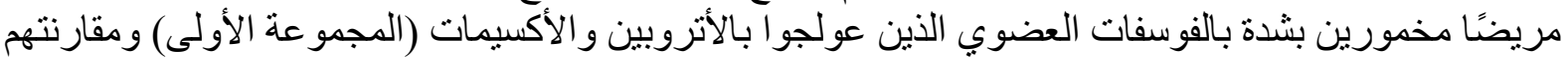

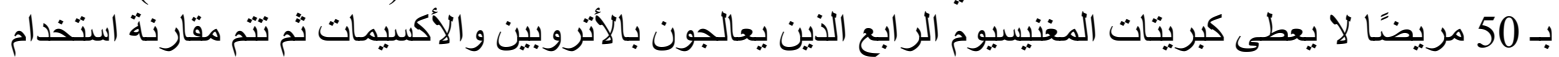

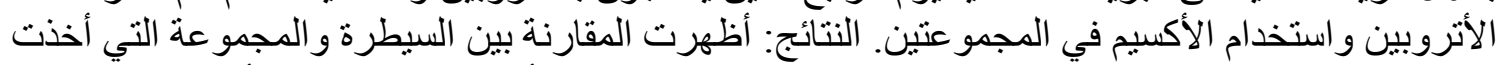

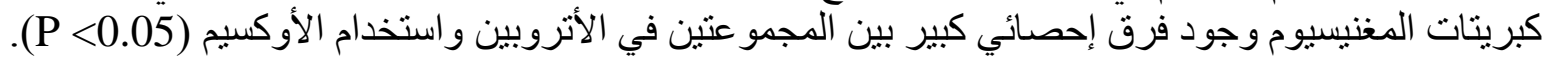

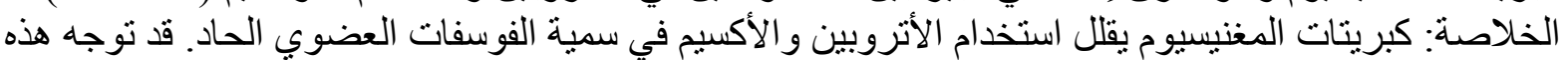

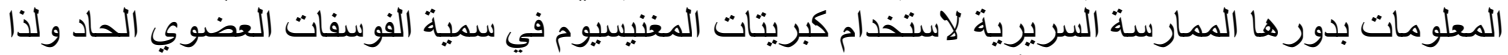

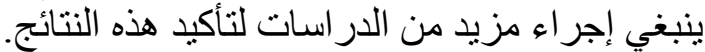
الكلمات المفتاحية: سلفات المغنيزيوم ـ سمية الفوسفات العضوري العضي الحاد ـ استخدام الأتروبين ـ استخدام الأكسيم 